\title{
PENGARUH PERHATIAN ORANG TUA DAN KEMANDIRIAN BELAJAR TERHADAP PRESTASI BELAJAR IPS SISWA DI SDN 130 KARAMBUA DESA RINJANI KECAMATAN WOTU KABUPATEN LUWU TIMUR
}

\author{
Ardillah Abu \\ Program Studi Tadris Ilmu Pengetahuan Sosial, FTIK, IAIN Palu \\ ardillahabu5@gmail.com
}

\begin{abstract}
ABSTRAK
Penelitian ini bertujuan untuk mengetahui (i) Pengaruh Perhatian Orang Tua terhadap Prestasi Belajar IPS Siswa di SDN 130 Karambua. (ii) Pengaruh Kemandirian Belajar terhadap Prestasi Belajar IPS Siswa di SDN 130 Karambua. (iii) Pengaruh Perhatian Orang Tua dan Kemandirian Belajar secara bersama-sama terhadap Prestasi Belajar IPS Siswa di SDN 130 Karambua, Desa Rinjani, Kecamatan Wotu. Jenis Penelitian merupakan adalah expost facto. Analisis data yang digunakan adalah teknik analisis regresi sederhana untuk hipotesis pertama dan kedua serta analisis regresi ganda untuk hipotesis ketiga. Sebelum analisis data terlebih dahulu diadakan pengujian persyaratan analisis meliputi: Normalitas, homogenitas, independen $t$ test, dan uji linearitas. Hasil penelitian ini adalah: (i) Terdapat pengaruh positif dan signifikan Perhatian Orang Tua terhadap Prestasi Belajar IPS Siswa di SDN 130 Karambua, dengan $\mathrm{r}_{\mathrm{x}} 1 \mathrm{y}$ $=0,516 ; \mathrm{r}^{2} \mathrm{x} 1 \mathrm{y}=0,266$; dan $\mathrm{t}_{\text {hitung }}$ lebih besar dari $\mathrm{t}_{\text {tabel }}$ yaitu: $3,85>1,701$. (ii) Terdapat pengaruh positif dan signifikan Kemandirian Belajar terhadap Prestasi Belajar IPS Siswa di SDN 130 Karambua, dengan $r_{x} 2 y=0,372 ; r^{2} x 2 y=0,138$; dan $t_{\text {hitung }}$ lebih besar dari $t_{\text {tabel }}$ yaitu: $2,119>1,701$. (iii) Terdapat pengaruh positif dan signifikan Perhatian Orang Tua dan Kemandirian Belajar secara bersama-sama

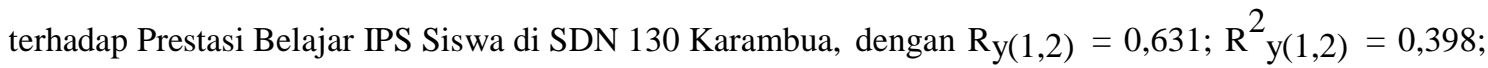
dan $\mathrm{F}_{\text {hitung }}$ lebih besar dari $\mathrm{F}_{\text {tabel }}$ yaitu: $5,542>3,35$ pada taraf signifikansi 5\%. Persamaan garis regresi $\mathrm{Y}=0,615 \mathrm{X}_{1}+-0,252 \mathrm{X}_{2}+51,198$.
\end{abstract}

Kata Kunci : Perhatian Orang tua, Kemandirian belajar, dan Prestasi Belajar IPS.

\begin{abstract}
This study aims to determine (i) The Effect of Parents' Attention on Social Studies Student Achievement at SDN 130 Karambua. (ii) The Effect of Learning Independence on Social Studies Learning Achievement of Students at SDN 130 Karambua. (iii) Effects of Parental Attention and Learning Independence together on Social Studies Achievement of Students at SDN 130 Karambua, Rinjani Village, Wotu District. This type of research is expost facto. Data analysis used was a simple regression analysis technique for the first and second hypotheses and multiple regression analysis for the third hypothesis. Before analyzing the data, an analysis of the requirements for testing is carried out including: normality, homogeneity, independent t test and linearity test The results of this study are: (i) There is a positive and significant influence of Parents' Attention on Social Studies Student Achievement at SDN 130 Karambua, with rxly = 0.516; $r^{2} x 1 y=0.266$;

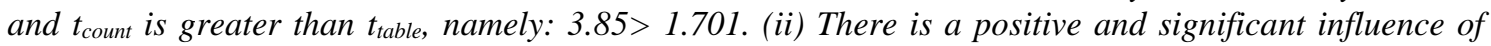
Learning Independence on Social Studies Achievement of Students in SDN 130 Karambua, with rx2y = $0.372 ; r^{2} x 2 y=0.138$; and $t_{\text {count }}$ is greater than $t_{\text {table, }}$, namely: 2.119>1.701. (iii) There is a positive and significant influence of Parental Attention and Learning Independence together on Social Studies Achievement of Students in SDN 130 Karambua, with Ry $(1,2)=0.631 ; R^{2} y(1,2)=0.398$; and $F_{\text {count }}$ is
\end{abstract}


greater than $F_{\text {table }}$ namely: $5.542>3.35$ at a significance level of 5\%. The regression line equation $Y=$ $0.615 X 1+-0.252 X 2+51.198$.

Keywords : parents' attention, learning independence, and social studies learning achievement

\section{PENDAHULUAN}

Sebagaimana tertuang dalam UndangUndang RI Nomor 20 Tahun 2003 tentang Sistem Pendidikan Nasional Pasal 3. Pendidikan merupakan suatu elemen penting dalam rangka meningkatkan dan mengembangkan kualitas sumber daya manusia. Salah satu cara untuk mengembangkan dan meningkatkan kualitas sumber daya manusia adalah dengan belajar. Belajar dapat dilakukan di mana saja dan kapan saja. Kualitas pendidikan di sekolah pada umumnya dapat dilihat dari prestasi belajar siswa-siswa di sekolah tersebut, dan dari prestasi belajar tersebut dapat dijadikan tolok ukur bagaimana pemahaman dan pengetahuan siswa terhadap mata pelajaran.

Prestasi Belajar Ilmu Pengetahuan Sosial (IPS) adalah tingkat pengetahuan, keterampilan, dan nilai sikap siswa tentang seberapa jauh siswa tersebut menangkap dan memahami mata pelajaran IPS serta siswa tersebut mampu mengimplementasikan keterampilan dan kompetensi belajar IPS yang telah diterima selama mengikuti proses belajar di sekolah. Melalui pelaksanaan evaluasi hasil belajar tersebut, maka akan dapat dilihat prestasi belajar siswa yang dicapai selama mengikuti proses belajar mengajar mata pelajaran IPS. Prestasi Belajar IPS juga memiliki peran penting sebagai indikator dari kualitas pendidikan di sekolah.

Proses belajar IPS merupakan suatu sistem yang terdiri dari input, proses dan output. Input berkaitan dengan peserta didik yang akan melaksanakan aktivitas belajar. Proses adalah kegiatan yang dilakukan siswa dalam mencapai tujuan pengajaran. Output merupakan hasil belajar atau kemampuankemampuan yang dimiliki siswa setelah ia menerima pengalaman belajarnya. Dalam melaksanakan proses belajar mengajar harus ada tujuan yang akan dicapai, sehingga perlu adanya suatu tes atau ulangan. Dari hasil tes atau ulangan tersebut dapat diketahui seberapa besar perubahan maupun kecakapan yang telah diperoleh seseorang peserta didik. Uraian di atas sejalan dengan pendapat Winkel yang menyatakan bahwa, "Prestasi merupakan suatu kecakapan nyata yang dimiliki oleh seseorang dan merupakan hasil dari proses yang dilakukannya" (Winkel, 2009: 161).

Menurut Nana Sudjana (2005:3), "prestasi belajar merupakan hasil-hasil belajar yang dicapai siswa dengan kriteria tertentu". Menurut Muhibbin Syah (2008:141), "prestasi belajar adalah tingkat keberhasilan dari siswa dalam mencapai tujuan yang telah ditetapkan dalam sebuah program. Alat ukur yang biasa digunakan untuk mengukur tingkat keberhasilan dari siswa adalah assesment atau yang dikenal dengan tes".

Prestasi Belajar IPS dipengaruhi oleh dua faktor yaitu faktor dari dalam dan faktor dari luar. Faktor-faktor tersebut adalah faktor dari dalam yaitu faktor kematangan, motivasi dan kemandirian. Faktor dari luar yaitu keluarga, lingkungan dan kesempatan yang tersedia (M. Ngalim Purwanto 2010:102). Banyak faktor yang dapat mempengaruhi tinggi-rendahnya Prestasi Belajar IPS. Salah satu faktor yang dapat mempengaruhi Prestasi Belajar IPS tersebut adalah Perhatian Orang Tua.

Keluarga merupakan kelompok sosial yang pertama dimana anak dapat berinteraksi, pengaruh keluarga dalam pembentukan dan perkembangan kepribadian sangatlah besar artinya. Oleh karena itu, peran orang tua sangat penting dalam perkembangan anaknya termasuk dalam hal keberhasilan pendidikannya, karena orang tua merupakan inti dari sebuah keluarga tersebut. Wujud dari peranan orang tua terhadap keberhasilan pendidikan anaknya adalah dengan memberikan perhatian. Perhatian Orang Tua memiliki pengaruh yang besar terhadap kegiatan belajar anak. Dengan adanya Perhatian Orang Tua, anak akan lebih giat dan lebih bersemangat dalam belajar karena ia tahu bahwa bukan dirinya 
sendiri saja yang berkeinginan untuk maju, akan tetapi orang tuanya pun demikian.

Baik buruknya prestasi yang dicapai anak akan memberikan pengaruh kepadanya dalam perkembangan pendidikan selanjutnya. Kurangnya Perhatian Orang Tua akan memberikan dampak yang negatif terhadap kegiatan anak. Apabila orang tua terkesan cuek terhadap kegiatan belajarnya, tidak memberikan kebutuhannya untuk belajar, maka anak akan menjadi malasmalasan dalam belajar. Tidak adanya Perhatian Orang Tua juga mengakibatkan kurangnya dorongan semangat untuk siswa atau anak tersebut sehingga anak tidak memiliki semangat dalam belajar.

Faktor lain yang dapat mempengaruhi Prestasi Belajar IPS adalah Kemandirian Belajar. Siswa sebagai subjek didik yang memiliki karakteristik berbeda-beda. Menurut pendapat dari Umar Tirtarahardja dan La Sulo (2005:52-53) "ciri-ciri peserta didik antara lain adalah individu yang memiliki kemampuan mandiri". Kemandirian pada seseorang tidak terbentuk begitu saja tetapi melalui sebuah proses panjang yang berawal dari ketergantungan yang tinggi pada orang lain yang kemudian berkurang secara perlahan-lahan dan akhirnya tumbuh kesadaran pada dirinya sendiri.

Menurut Haris Mudjiman (2007:7) Kemandirian Belajar adalah kegiatan belajar aktif yang didorong oleh niat atau motif untuk menguasai suatu kompetensi guna mengatasi suatu masalah. Sedangkan menurut Mohammad Ali dan Mohammad Asrori (2005: 114) "kemandirian merupakan suatu kekuatan internal individu yang diperoleh melalui proses individuasi". Menurut Umar Tirtarahardja dan La Sulo (2005: 50) "kemandirian dalam belajar diartikan sebagai aktivitas belajar yang berlangsungnya lebih didorong oleh kemauan sendiri, pilihan sendiri, dan tanggung jawab sendiri dari pembelajar". Konsep kemandirian dalam belajar bertumpu pada prinsip bahwa individu yang belajar hanya akan sampai kepada perolehan hasil belajar, mulai keterampilan, pengembangan penalaran, pembentukan sikap sampai kepada penemuan diri sendiri, apabila mengalami sendiri dalam proses perolehan hasil belajar tersebut.
Menurut Abu Ahmadi (1991:31) "kemandirian belajar adalah sebagai belajar secara mandiri, tidak menggantungkan diri pada orang lain". Perkembangan kemandirian adalah proses yang menyangkut unsur-unsur normatif. Ini mengandung makna bahwa kemandirian merupakan suatu proses yang terarah. Oleh karena perkembangan kemandirian sejalan dengan hakikat eksistensi manusia, arah perkembangan tersebut harus sejalan dan berlandaskan pada tujuan hidup manusia (Mohammad Ali dan Mohammad Asrori, 2005:112).

Berdasarkan permasalahan tersebut di atas, penulis tertarik untuk mengadakan penelitian lebih mendalam yang dituangkan dalam bentuk tesis dengan judul: "Pengaruh Perhatian Orang Tua dan Kemandirian Belajar terhadap Prestasi Belajar IPS Siswa di SDN 130 Karambua, Desa Rinjani, Kecamatan Wotu".

\section{METODE PENELITIAN}

Penelitian ini termasuk penelitian expost facto, karena penelitian ini meneliti tentang variabel yang kejadiannya sudah terjadi sebelum dilaksanakan. Pendekatan yang digunakan adalah pendekatan kuantitatif karena penelitian ini meneliti populasi tertentu, pengumpulan data menggunakan instrumen penelitian, analisis data bersifat kuantitatif/statistik, dengan tujuan untuk menguji hipotesis yang telah ditetapkan. Penelitian ini juga merupakan penelitian kausal komparatif karena penelitian ini memiliki tujuan untuk mengetahui kemungkinan adanya sebab akibat yang diamati dari akibat yang telah terjadi disana dengan cara tertentu dan mengumpulkan data tertentu untuk mencari lagi fakta yang mungkin menjadi penyebabnya.

Dalam penelitian ini, yang menjadi populasi adalah seluruh siswa SDN 130 Karambua, Desa Rinjani, Kecamatan Wotu Kelas tinggi (Kelas IV, V dan VI) yang berjumlah 137 orang siswa. Besaran sampel yang digunakan didasarkan pada pendapat Arikunto (2006: 134) yang menjelaskan dalam bahwa sebagai pedoman dalam pemilihan sampel apabila subjek kurang dari 100 lebih baik diambil semua, tetapi apabila 
subjek banyak/lebih dari 100 maka sampel dapat diambil sebanyak $10 \%-15 \%$ atau $20 \%$ $25 \%$ atau lebih sesuai dengan kemampuan peneliti dari segi waktu, tenaga dan dana yang dibutuhkan. Berdasarkan pendapat diatas, maka peneliti mengambil sampel $22 \%$ dari anggota populasi yang berjumlah 137 orang.

Sebelum menggunakan uji hipotesa, terlebih dahulu dilakukan uji statistik yang berupa statistik deskriptif. Analisa deskriptif merupakan pengolahan data dari proses tabulasi menjadi data yang mudah dipahami dan interprestasikan.

\section{a. Uji Prasyarat Analisis}

\section{1) Uji Normalitas}

Uji normalitas bertujuan untuk menguji apakah model regresi, variabel independen dan variable dependennya memiliki distribusi normal atau tidak.

\section{2) Uji Homogenitas}

Uji homogenitas data menggunakan Levene's test for Equality of Varience dibantu dengan software SPSS versi 20,0 for Windows dengan kriteria pengujian yang digunakan adalah sig $>\alpha$ dengan taraf $\alpha=0,05$.

\section{3) Uji Independen}

Setelah semua data telah terpenuhi syaratnya untuk uji Independen, meliputi uji homogenitas dan uji normalitas.

\section{4) Uji Linieritas}

Uji linieritas untuk mengetahui apakah pengaruh masing-masing variabel bebas yang dijadikan prediktor mempunyai hubungan linier atau tidak terhadap variabel terikat.

b. Uji Hipotesis

\section{1) Analisis Regresi Sederhana}

Analisis ini digunakan untuk menguji pengaruh variabel bebas terhadap variabel terikat secara individual. Hipotesis I dan hipotesis II diuji dengan menggunakan analisis regresi sederhana.

\section{HASIL DAN PEMBAHASAN}

\section{A. Deskripsi Data Hasil Penelitian}

1. Analisis Deskriptif Perhatian Orang Tua Siswa di SDN 130 Karambua.

Variabel Perhatian Orang Tua (X1) diukur melalui angket dengan 19 butir pernyataan. Berdasarkan data yang diperoleh dari angket yang disebarkan kepada 30 responden menunjukkan bahwa variabel Perhatian Orang Tua (X1) diperoleh skor tertinggi sebesar 76 dari skor tertinggi yang mungkin dicapai sebesar $(4 \times 19)=76$ dan skor terendah sebesar 49 dari skor terendah yang mungkin dicapai sebesar $(1 \times 19)=19$. Dari skor tersebut kemudian dianalisis dengan menggunakan SPSS Statistics 20,0 for Windows diperoleh harga Mean (M) sebesar 68,03; Median (Me) sebesar 68,50; Mode sebesar 65; Varians sebesar 40,93; dan Standar Deviasi sebesar 6,398.

Menunjukkan bahwa terdapat 2 siswa $(6,7 \%)$ yang menilai Perhatian Orang Tua berada dalam kategori sangat kurang, 1 siswa $(3,3 \%)$ dalam kategori kurang, 13 siswa $(43,3 \%)$ yang berada dalam kategori baik dan 14 siswa $(46,7 \%)$ dalam kategori sangat baik.

2. Analisis Deskriptif Kemandirian Belajar Siswa di SDN 130 Karambua

Variabel Kemandirian Belajar $\left(\mathrm{X}_{2}\right)$ diukur melalui angket dengan 21 butir pernyataan. Berdasarkan data yang didapat dari 30 responden diperoleh skor tertinggi sebesar 75 dari skor tertinggi yang mungkin dicapai sebesar $(4 \times 21)=84$ dan skor terendah sebesar 49 dari skor terendah yang mungkin dicapai $(1 \times 21)=21$. Dari skor tersebut kemudian dianalisis dengan menggunakan SPSS Statistics 20.0 for windows diperoleh harga Mean (M) sebesar 65,9; Median (Me) sebesar 67; Mode sebesar 63; Varians sebesar 40,024; dan Standar Deviasi sebesar 6,326.

Menunjukkan bahwa terdapat 2 siswa $(6,7 \%)$ yang berada dalam kategori sangat kurang, 3 siswa (10\%) dalam kategori kurang, 16 siswa $(53,3 \%)$ dalam kategori baik dan terdapat 30 siswa $(30 \%)$ dalam kategori sangat baik.

3. Analisis Deskriptif Prestasi Belajar IPS Siswa di SDN 130 Karambua.

Data mengenai variabel Prestasi Belajar IPS siswa dalam penelitian ini diperoleh melalui dokumentasi yaitu dilihat dari satu nilai ulangan harian, nilai ulangan tengah semester, dan nilai Semester yang masing-masing memiliki bobot nilai $20 \%$, $40 \%$, dan $40 \%$. Berdasarkan data variabel Prestasi Belajar IPS siswa di SDN 130 Karambua, Desa Rinjani, Kecamatan Wotu, 
yang diolah menggunakan program SPSS Statistics 20.0 for windows maka diperoleh nilai tertinggi sebesar 90 dan nilai terendah sebesar 70. Hasil analisis menunjukkan nilai Mean sebesar 77,13; Median sebesar 76; Mode sebesar 76; Varians sebesar 24,326; dan Standar Deviasi sebesar 4,932; dan Variance sebesar 22,407.

Berdasarkan tabel dan histogram di atas, frekuensi variabel Prestasi Belajar IPS pada interval 67 - 70 sebanyak 2 siswa $(6,7 \%)$, interval $71-74$ sebanyak 7 siswa $(23,3 \%)$, interval $75-78$ sebanyak 10 siswa $(33,3 \%)$, interval $79-82$ sebanyak 8 siswa $(26,7 \%)$, interval $83-86$ sebanyak 2 siswa $(6,7 \%)$, interval $87-90$ sebanyak 1 siswa $(3,3 \%)$.

Berdasarkan tabel di atas frekuensi variabel Prestasi Belajar IPS pada kategori tidak tuntas sebanyak 9 siswa (30\%). Frekuensi variabel Prestasi Belajar IPS kategori tuntas sebanyak 21 siswa (70\%).

\section{B. Pengujian Hipotesis}

\section{Uji hipotesis I}

Hipotesis pertama yang akan diuji dalam penelitian ini adalah terdapat pengaruh positif Perhatian Orang Tua terhadap Prestasi Belajar IPS Siswa. Untuk menguji hipotesis tersebut digunakan analisis regresi sederhana. Persamaan Garis Regresi.

Berdasarkan tabel di atas, maka persamaan regresi dapat dinyatakan dalam persamaan sebagai berikut:

$$
\mathrm{Y}=0,398 \mathrm{X}_{1}+50,398
$$

Persamaan tersebut menunjukkan bahwa nilai koefisien regresi bernilai positif sebesar 0,398 yang berarti jika nilai Perhatian Orang Tua (X1) naik 1 satuan maka Prestasi Belajar IPS (Y) naik sebesar 0,398.

a) Koefien Korelasi dan Koefisien Determinasi

Hasil analisis regresi sederhana dengan satu prediktor menunjukkan koefisien korelasi (r) sebesar 0,516 dengan koefisien determinasi $\left(\mathrm{r}^{2}\right) 0,266$, hal ini berarti bahwa Perhatian Orang Tua mampu mempengaruhi 26,6\% perubahan pada Prestasi Belajar IPS Siswa di SDN 130 Karambua, Desa Rinjani. Hal ini menunjukkan, masih ada $73,4 \%$ faktor atau variabel lain yang kemungkinan berpengaruh terhadap Prestasi Belajar IPS Siswa di SDN 130 Karambua, Desa Rinjani.

b) Pengujian Signifikansi Regresi Sederhana.

Pengujian signifikansi bertujuan untuk mengetahui keberartian variabel Perhatian Orang Tua terhadap Prestasi Belajar IPS. Hipotesis yang diuji menunjukkan terdapat pengaruh positif Perhatian Orang Tua terhadap Prestasi Belajar IPS Siswa. Pengujian signifikansi dengan uji $t$ diperoleh harga thitung yang dihasilkan 3,85, sehingga hipotesis yang menyatakan bahwa terdapat pengaruh positif Perhatian Orang Tua terhadap Prestasi Belajar IPS dapat diterima. Harga tabel dengan taraf signifikansi 5\% sebesar 1,701. Hal ini berarti bahwa thitung lebih besar dari tabel $(3,85$ > 1,708), sehingga Perhatian Orang Tua mempunyai pengaruh positif dan signifikan terhadap Prestasi Belajar IPS Siswa di SDN 130 Karambua, Desa Rinjani.

\section{Uji hipotesis II}

Hipotesis kedua yang akan diuji dalam penelitian ini adalah terdapat pengaruh positif Kemandirian Belajar terhadap Prestasi Belajar IPS Siswa. Untuk menguji hipotesis tersebut digunakan analisis regresi sederhana.

a) Persamaan Garis Regresi

Berdasarkan tabel di atas, maka persamaan regresi dapat dinyatakan dalam persamaan sebagai berikut:

$$
\mathrm{Y}=0,29 \mathrm{X}_{2}+58,034
$$

Persamaan tersebut menunjukkan bahwa nilai koefisien regresi bernilai positif sebesar 0,29 yang berarti jika nilai Kemandirian Belajar ( $\left.\mathrm{X}_{2}\right)$ naik 1 satuan maka Prestasi Belajar IPS (Y) naik sebesar 0,29.

b) Koefien Korelasi dan Koefisien Determinasi

Hasil analisis regresi sederhana dengan satu prediktor menunjukkan koefisien korelasi (r) sebesar 0,372 dengan koefisien determinasi $\left(\mathrm{r}^{2}\right) 0,138$, hal ini berarti bahwa Kemandirian Belajar mampu mempengaruhi $13,8 \%$ perubahan 
pada Prestasi Belajar IPS Siswa di SDN 130 Karambua, Desa Rinjani. Hal ini menunjukkan, masih ada $86,2 \%$ faktor atau variabel lain yang kemungkinan berpengaruh terhadap Prestasi Belajar IPS Siswa di SDN 130 Karambua, Desa Rinjani.

c) Pengujian Signifikansi Regresi Sederhana

Pengujian signifikansi bertujuan untuk mengetahui pengaruh positif variabel Kemandirian Belajar terhadap Prestasi Belajar IPS. Hipotesis yang diuji terdapat pengaruh Kemandirian Belajar terhadap Prestasi Belajar IPS. Pengujian signifikansi dengan uji t diperoleh harga thitung yang dihasilkan 2,119 sehingga hipotesis yang menyatakan bahwa terdapat pengaruh positif Kemandirian Belajar terhadap Prestasi Belajar IPS. Hipotesis yang diuji menunjukkan terdapat pengaruh positif dan signifikan Kemandirian Belajar terhadap Prestasi Belajar IPS Siswa di SDN 130 Karambua, Desa Rinjani dapat diterima. Harga ttabel dengan taraf signifikansi $5 \%$ sebesar 1,701. Hal ini berarti bahwa thitung lebih besar dari tabel (2,119>1,701), sehingga Kemandirian Belajar memiliki pengaruh postif dan signifikan terhadap Prestasi Belajar IPS Siswa di SDN 130 Karambua, Desa Rinjani.

\section{Uji Hipotesis III}

Hipotesis ketiga yang akan diuji dalam penelitian ini adalah terdapat pengaruh positif Perhatian Orang Tua dan Kemandirian Belajar terhadap Prestasi Belajar IPS Siswa. Untuk menguji hipotesis tersebut digunakan analisis regresi ganda. Ringkasan hasil pengujian hipotesis ketiga dapat dilihat pada tabel berikut:

a) Persamaan Garis Regresi

Berdasarkan tabel di atas, maka persamaan regresi dapat dinyatakan dalam persamaan sebagai berikut:

$$
\mathrm{Y}=0,615 \mathrm{X}_{1}+-0,252 \mathrm{X}_{2}+51,198
$$

Persamaan tersebut menunjukkan bahwa nilai koefisien $\mathrm{X}_{1}$ sebesar 0,615 artinya, apabila nilai Perhatian Orang Tua (X1) meningkat 1 poin maka nilai Prestasi Belajar IPS (Y) akan meningkat sebesar 0,615 poin, dengan asumsi $\mathrm{X}_{2}$ tetap.
Koefisien $\mathrm{X}_{2}$ sebesar $-0,252$ artinya apabila Kemandirian Belajar (X2) meningkat 1 poin maka pertambahan nilai pada Prestasi Belajar (Y) sebesar $-0,252$ poin, dengan asumsi $X_{1}$ tetap.

b) Koefien Korelasi dan Koefisien Determinasi

Hasil perhitungan SPSS Statistics 20.0 menujukkan harga koefisien korelasi (R) sebesar 0,539 dan harga koefisien determinasi $\left(\mathrm{R}^{2}\right)$ sebesar 0,239 . Nilai tersebut berarti $23,9 \%$ perubahan variabel Prestasi Belajar IPS (Y) dapat diterangkan oleh Perhatian Orang Tua (X1) dan Kemandirian Belajar (X2), sedangkan $76,1 \%$ dijelaskan variabel lain yang tidak diteliti dalam penelitian ini.

c) Pengujian Signifikansi Regresi Ganda

Pengujian signifikansi bertujuan untuk mengetahui keberartian variabel Perhatian Orang Tua dan Kemandirian Belajar terhadap Prestasi Belajar IPS. Hipotesis yang diuji terdapat pengaruh positif Perhatian Orang Tua dan Kemandirian Belajar terhadap Prestasi Belajar IPS Siswa di SDN 130 Karambua, Desa Rinjani. Uji signifikansi menggunakan uji $\mathrm{F}$, berdasarkan hasil uji F diperoleh Fhitung sebesar 5,542 sehingga hipotesis yang menyatakan bahwa terdapat pengaruh positif dan signifikan Perhatian Orang Tua dan Kemandirian Belajar terhadap Prestasi Belajar IPS Siswa di SDN 130 Karambua, Desa Rinjani dapat diterima. Jika dibandingkan dengan nilai $\mathrm{F}_{\text {tabel }}$ sebesar 3,35 pada taraf signifikansi 5\%, maka 5,542 > 3,40 (Fhitung > Ftabel) sehingga Perhatian Orang Tua dan Kemandirian Belajar mempunyai pengaruh positif dan signifikan secara bersama-sama terhadap Prestasi Belajar IPS Siswa di SDN 130 Karambua, Desa Rinjani.

\section{KESIMPULAN}

Berdasarkan pembahasan yang telah diuraikan sebelumnya, maka diperoleh kesimpulan sebagai berikut:

1. Terdapat pengaruh positif dan signifikan Perhatian Orang Tua terhadap Prestasi Belajar IPS Siswa di SDN 130 
Karambua, Desa Rinjani.

2. Terdapat pengaruh positif dan signifikan Kemandirian Belajar terhadap Prestasi Belajar IPS Siswa di SDN 130 Karambua, Desa Rinjani.

3. Terdapat pengaruh positif dan signifikan Perhatian Orang Tua dan Kemandirian Belajar secara bersamasama terhadap Prestasi Belajar IPS Siswa di SDN 130 Karambua, Desa Rinjani.

\section{SARAN}

Berdasarkan hasil penelitian dan kesimpulan di atas maka dapat diberikan saran-saran sebagai

1. Saran bagi guru

Berdasarkan data yang diperoleh dari pengisian angket Kemadirian Belajar, juga terdapat beberapa item yang memiliki skor rendah antara lain siswa hanya belajar IPS pada saat akan diadakan ulangan, dan selalu meminta orang lain untuk menyelesaikan masalah dalam belajarnya. Oleh karena itu, guru diharapkan untuk dapat mendorong siswa untuk selalu belajar IPS, tidak hanya pada saat ulangan saja. Selain itu guru juga diharapkan untuk membimbing dan memberikan dorongan kepada siswa untuk lebih percaya diri dalam menyelesaikan masalah belajarnya, dan dengan adanya kesadaran siswa untuk terus belajar dan adanya kepercayaan diri dalam menyelesaikan masalah belajarnya maka akan meningkatkan Prestasi Belajar IPS siswa.

2. Saran bagi orang tua

Berdasarkan data yang diperoleh dari pengisian angket Perhatian Orang Tua, terdapat item yang memiliki skor rendah, yaitu orang tua tidak memberikan sanksi ketika anak tidak belajar. Berdasarkan hal tersebut, orang tua diharapkan lebih memperhatikan kegiatan belajar anaknya dan apabila anak tidak belajar maka orang tua sebaiknya memberikan sanksi kepada anaknya agar dapat mendorong anak untuk lebih giat dalam belajar, dengan semakin giat belajar maka Prestasi Belajar IPS nya dapat meningkat.
3. Saran bagi siswa

Belajar adalah tanggung jawab utama bagi seorang siswa, dalam belajar hendaknya siswa memperhatikan beberapa hal yang dapat memaksimalkan proses belajar tersebut guna memperoleh hasil belajar yang maksimal, salah satunya adalah dengan meningkatkan kepercayaan diri dalam menyelesaikan masalah belajarnya. Selain itu siswa diharapkan untuk selalu belajar IPS dan tidak hanya belajar pada saat akan diadakan ulangan saja, hal ini perlu dilakukan agar siswa dapat meningkatkan kemampuannya dalam mata pelajaran IPS sehingga Prestasi Belajar IPS akan ikut meningkat.

\section{DAFTAR PUSTAKA}

Ahmadi, A. (2009). Teknik Belajar Yang Efektif. Jakarta : Rineka Cipta.

Ali, M \& Asrori, M. (2004). Psikologi Remaja Perkembangan Peserta Didik. Jakarta: Bumi Aksara.

Al-Lamri Ichas Hamid dan Tuti Istianti Ichas. (2006). Pengembangan Pendidikan Nilai dalam Pembelajaran Pengetahuan Sosial di Sekolah Dasar. Jakarta : Departemen Pendidikan Nasional.

Anggoro, M. T. (2007). Metode Penelitian. Universitas Terbuka: Jakarta.

Arikunto, S. (2006). Prosedur Penelitian: Suatu Pendekatan Praktik, Jakarta : Rineka Cipta.

. (2010). Prosedur penelitian: Suatu Pendekatan Praktik. (Edisi. Revisi). Jakarta : Rineka Cipta

Balitbang, P. (2001). Keterampilanketerampilan Sejarah, Geografi, Sosiologi, Antropologi, dan Ekonomi. Jakarta: Depdiknas

Basri, H. (2004). Remaja Berkualitas. Problematika Remaja dan Solusinya. Yogyakarta: Mitra Pustaka. 
Ardillah Abu

Basri, L.O, Kemandirian Belajar atau Belajar Mandiri. (www.smadwiwarna.net) Diakses tanggal 23 Desember 2015.

Budikusuma, A. (2013). Pengaruh Perhatian Orang Tua dan Kemandirian Belajar terhadap Prestasi Belajar Akuntansi Siswa Kelas IX IPS SMA Negeri 3 Magelang Tahun Ajaran 2012/2013. Skripsi. Yogyakarta: Pendidikan Akuntansi FE UNY.

Bungin, B. (2005). Metodologi Penelitian Kuantitatif. Jakarta: Kencana Prenada Media. Group 